\title{
Penerapan Model Regresi Data Panel pada Faktor Fundamental dan Teknikal Harga Saham Sektor Industri Real Estate
}

\author{
Novi Saputri ${ }^{1,}$ a) , Budi Nurani Ruchjana ${ }^{1, b)}$, Endang Soeryana Hasbullah ${ }^{1, c)}$ \\ ${ }^{1}$ Departemen Matematika, Fakultas MIPA, Universitas Padjadjaran \\ a) email: novisaputri18@gmail.com \\ b)email: budi.nurani@unpad.ac.id \\ c)email: endang.soeryana@unpad.ac.id
}

\begin{abstract}
Abstrak
Regresi data panel merupakan regresi yang menggabungkan data runtut waktu dan data antar individu. Salah satu model regresi data panel adalah model fixed effect. Model ini mengasumsikan bahwa koefisien slope bernilai konstan, tetapi koefisien intersep bervariasi sepanjang individu. Estimasi yang dilakukan yaitu dengan penambahan variabel dummy untuk menjelaskan perbedaan karakteristik antar individual atau biasa disebut metode least square dummy variable. Data yang digunakan merupakan data dari Bursa Efek Indonesia yang diduga berpengaruh terhadap harga saham. Terdapat dua pendekatan yang digunakan untuk mempengaruhi harga saham, yaitu faktor fundamental dan faktor teknikal. Pada penelitian ini, variabel faktor fundamentalnya adalah return on asset (ROA), price to book value (PBV), earning per share (EPS) dan debt to equtity ratio (DER). Sedangkan variabel faktor teknikalnya adalah volume perdagangan saham (VS). Berdasarkan hasil analisis, model mengalami masalah autokorelasi dan heteroskedastisitas, sehingga model fixed effect lebih baik diestimasi dengan metode seemingly uncorrelated regression. Hasil yang diperoleh dari penelitian ini adalah variabel faktor fundamental dan teknikal mempengaruhi harga saham di masing-masing perusahaan sektor industri real estate yang terdaftar di Bursa Efek Indoesia secara simultan maupun parsial.
\end{abstract}

Kata kunci: Fixed Effect, Harga Saham, Least Square Dummy Variable, Regresi Data Panel, Seemingly Uncorrelated Regression

\begin{abstract}
Panel data regression is a regression that combines time series data and cross section data. One of the panel data regression model is the fixed effect model. This model assumes that the slope coefficient is constant but the intercept coefficient are varies over individuals. Estimates done by using dummy variables to explain differences between individuals characteristics or commonly referred as least square dummy variable. There are two approaches used to influence stock prices, namely fundamental factors and technical factors. In this research, fundamental factor variables are return on asset (ROA), price to book
\end{abstract}

e-ISSN: 2686-0341 p-ISSN: 2338-0896 
value (PBV), earning per share (EPS) and debt to equtity ratio (DER). While technical factor variable is trading volume activity (VS). Based on the results of the analysis, this model experiences autocorrelation and heteroscedasticity problems, so fixed effect model is better estimated using seemingly uncorrelated regression method. The result obtained from this study are fundamental and technical factor variabels influence the stock price in each company in real estate industrial sector listed on the Indonesia Stock Exchange simultaneously and partially.

Keywords: Fixed Effect, Least Square Dummy Variable, Panel Data Regression, Seemingly Uncorrelated Regression, Stock Price.

\section{Pendahuluan}

Indonesia merupakan salah satu negara berkembang yang sedang meningkatkan produktivitas perekonomian. Dalam rangka meningkatkan produktivitas perekonomian, lembaga-lembaga keuangan di Indonesia menawarkan investasi pasar modal. Salah satu sumber dana yang diperjualbelikan adalah kepemilikan saham. Saham merupakan investasi yang paling banyak diminati investor karena keuntungan yang diperoleh relatif lebih besar dan membutuhkan modal yang tidak begitu besar jika dibandingkan dengan obligasi. Dalam analisis sekuritas ada dua pendekatan yang mempengaruhi harga saham yaitu analisis fundamental dan analisis teknikal [3]. Analisis fundamental didasarkan pada rasio finansial perusahaan. Analisis teknikal didasarkan pada data perubahan (sebelumnya) untuk memperkirakan harga saham di masa mendatang.

Data panel merupakan penggabungan data runtut waktu (time series) dan data antar individu (cross section) [3]. Regresi dengan menggunakan data panel disebut regresi data panel. Pada data saham, normalnya memiliki nilai karakteristik/intersep antar perusahaan yang berbeda-beda, karena tidak bisa disamakan antara perusahaan kecil, besar, maupun menengah. Salah satu solusi permasalahan tersebut adalah model fixed effect. Model fixed effect adalah model regresi dengan penambahan variabel dummy untuk menjelaskan adanya perbedaan karakteristik/intersep antar individu maupun waktu. Sektor real estate dijadikan sebagai salah satu tolak ukur dalam menilai kemajuan ekonomi suatu negara karena melihat potensi jumlah penduduk yang terus bertambah besar dan meningkatnya pembangunan (perumahan, apartemen, pusat perbelanjaan, dan gedung-gedung perkantoran) yang membuat investor tertarik untuk menginvestasikan dananya.

Penelitian tentang harga saham telah dilakukan oleh beberapa peneliti sebelumnya, salah satunya pengaruh kinerja keuangan terhadap harga saham menggunakan Structural Equation Modeling Partial Least Square (SEMPLS) [1]. Serta pengaruh faktor fundamental dan teknikal terhadap harga saham menggunakan Model Regresi Linear Berganda [2]. Oleh karena itu, penelitian ini menerapkan Model Regresi Data Panel dengan pendekatan Fixed Effect Model menggunakan Metode Least Square Dummy Variable untuk menentukan pengaruh faktor fundamental dan teknikal terhadap harga saham sektor industri real estate di Bursa Efek Indonesia sehingga dapat digunakan menjadi referensi untuk orang yang ingin berinvestasi pada saham real estate.

\section{Metode}

\section{Data Panel}

Data panel diperkenalkan oleh Howles pada tahun 1950. Data panel merupakan penggabungan data runtut waktu (time series) dan data antar individu (cross section). Data panel dapat dibedakan menjadi 2 , 
yaitu; panel seimbang, terjadi jika setiap individu miliki panjang waktu observasi yang sama. Sedangkan panel tidak seimbang, terjadi jika setiap individu miliki panjang waktu observasi yang berbeda [3].

\section{Analisis Regresi Linear Berganda}

Regresi linear berganda berguna untuk mengkaji hubungan antara dua atau lebih variabel bebas terhadap variabel tak bebas. Secara umum bentuk persamaan regresi linier berganda sebagai berikut [3]:

$$
\begin{gathered}
y_{i}=\beta_{0}+\beta_{1} x_{1 i}+\beta_{2} x_{2 i}+\cdots+\beta_{j} x_{j i}+e_{i} \\
i=1,2, \ldots, n
\end{gathered}
$$

dimana $i$ menunjukkan objek sejumlah $n, x_{i}$ menunjukkan variabel bebas sejumlah $j, y_{i}$ menunjukkan variabel tak bebas, $\beta_{0}$ menunjukkan koefisien intersep, $\beta$ menunjukkan koefisien slope sejumlah $j$, dan $e_{i}$ menunjukkan residual objek $\left(e_{i} \sim N\left(0, \sigma^{2}\right)\right)$. Persamaan (1) dapat dianalogikan menjadi:

$$
\mathbf{y}=\mathbf{X} \boldsymbol{\beta}+\mathbf{e}
$$

dimana $\mathbf{y}$ adalah vektor kolom variabel tak bebas berukuran $n \times 1, \mathbf{X}$ adalah matriks variabel bebas berukuran $n \times(k+1), \boldsymbol{\beta}$ adalah vektor koefisien slope berukuran $(k+1) \times 1$, dan $\mathbf{e}$ adalah vektor kolom residual berukuran $n \times 1$.

\section{Analisis Regresi Data Panel}

Terdapat tiga pendekatan untuk menaksir model regresi data panel, yaitu Common Effect Model (CEM), Fixed Effect Model (FEM) dan Random Effects Model (REM) [3]. Karena peneliti ingin melihat perbedaan karakteristik antar individu, maka dipilih model estimasi Fixed Effect.

Perbedaan regresi data panel dengan regresi biasa, yaitu : 1). Data yang digunakan adalah data panel; 2). Datanya relatif lebih banyak, sehingga terhindar dari gejala multikolinearitas dan dapat memperbesar derajat kebebasan; 3). Memungkinkan estimasi pada masing-masing karakteristik individu maupun waktu secara terpisah.

\section{a. Fixed Effect Model (FEM)}

Fixed effect model atau model efek tetap adalah model yang memperhatikan adanya keberagaman variabel bebas menurut individu. Keberagamannya dilihat dari nilai intercept $\left(\beta_{0}\right)$ yang berbeda-beda antar individu. Sedangkan koefisien slope dari setiap variabel bebas diasumsikan sama untuk setiap individu sepanjang waktu observasinya. Secara umum bentuk fixed effect model sebagai berikut [3]:

$$
\begin{gathered}
y_{i t}=\beta_{0 i}+\sum_{k=1}^{j} \beta_{k} x_{k_{i t}}+e_{i t} \\
i=1,2, \ldots, N ; t=1,2, \ldots, T
\end{gathered}
$$

dimana $i$ menunjukkan objek sejumlah $N, t$ menunjukkan waktu sejumlah $T, x_{i t}$ menunjukkan variabel bebas sejumlah $j, y_{i t}$ menunjukkan variabel tak bebas, $\beta_{0 i}$ menunjukkan koefisien intersep, $\beta_{k}$ menunjukkan koefisien slope sejumlah $j$, dan $e_{i t}$ menunjukkan residual objek $\left(e_{i} \sim N\left(0, \sigma^{2}\right)\right)$.

\section{b. Least Square Dummy Variable (LSDV)}

Least square dummy variable adalah metode kuadrat terkecil dengan melibatkan variabel dummy (D) sebagai salah satu variabel bebasnya. Bentuk fixed effect model dengan metode LSDV sebagai berikut [3]:

$$
\begin{array}{r}
y_{i t}=\beta_{0 i} D_{i t}+\sum_{k=1}^{j} \beta_{k} x_{k i t}+e_{i t} \\
i=1,2, \ldots, N ; t=1,2, \ldots, T
\end{array}
$$

dimana $i$ menunjukkan objek sejumlah $N, t$ menunjukkan waktu sejumlah $T, x_{i t}$ menunjukkan variabel bebas sejumlah $j, y_{i t}$ menunjukkan variabel tak bebas, $\beta_{0 i}$ menunjukkan koefisien intersep, $D_{i t}$ menunjukkan perbedaan karakteristik antar individual ( $D_{i t}$ akan bernilai 1 jika $i=t$ serta bernilai 0 untuk 
yang lainnya), $\beta_{k}$ menunjukkan koefisien slope sejumlah $j$, dan $e_{i t}$ menunjukkan residual objek $\left(e_{i} \sim N\left(0, \sigma^{2}\right)\right)$.

Dengan menggunakan konstanta dan untuk menghindari kolinearitas sempurna yang tidak memungkinkan diperolehnya penaksiran parameter slope digunakan jumlah dummy sebanyak ( $\mathrm{N}-1$ ) [3]. Persamaan (4) dapat ditaksir dengan metode ordinary least square, sehingga menghasilkan:

$$
\begin{aligned}
& \widehat{\boldsymbol{\beta}}_{0}=\left[\begin{array}{c}
\bar{y}_{1}-\left(\hat{\beta}_{1} \bar{x}_{1_{1}}+\hat{\beta}_{2} \bar{x}_{2_{1}}+\cdots+\hat{\beta}_{j} \bar{x}_{j_{1}}\right) \\
\bar{y}_{2}-\left(\hat{\beta}_{1} \bar{x}_{1_{2}}+\hat{\beta}_{2} \bar{x}_{2_{2}}+\cdots+\hat{\beta}_{j} \bar{x}_{j_{2}}\right) \\
\vdots \\
\bar{y}_{N}-\left(\hat{\beta}_{1} \bar{x}_{1_{N}}+\hat{\beta}_{2} \bar{x}_{2_{N}}+\cdots+\hat{\beta}_{j} \bar{x}_{j_{N}}\right)
\end{array}\right] \\
& \widehat{\boldsymbol{\beta}}=\left[\begin{array}{ccc}
\sum_{i=1}^{N} \sum_{t=1}^{T}\left(x_{1 i t}-\bar{x}_{1 i}\right)^{2} & \cdots & \sum_{i=1}^{N} \sum_{t=1}^{T}\left(x_{1 i t}-\bar{x}_{1 i}\right)\left(x_{j_{i t}}-\bar{x}_{j_{i}}\right) \\
\sum_{i=1}^{N} \sum_{t=1}^{T}\left(x_{2 i t}-\bar{x}_{2 i}\right)\left(x_{1 i t}-\bar{x}_{1 i}\right) & \cdots & \sum_{i=1}^{N} \sum_{t=1}^{T}\left(x_{2_{i t}}-\bar{x}_{2 i}\right)\left(x_{j_{i t}}-\bar{x}_{j_{i}}\right) \\
\vdots & \ddots & \vdots \\
\sum_{i=1}^{N} \sum_{t=1}^{T}\left(x_{j_{i t}}-\bar{x}_{j i}\right)\left(x_{1_{i t}}-\bar{x}_{1 i}\right) & \cdots & \sum_{i=1}^{N} \sum_{t=1}^{T}\left(x_{j_{i t}}-\bar{x}_{j_{i}}\right)^{2}
\end{array}\right]^{-1} \cdot\left[\begin{array}{c}
\sum_{i=1}^{N} \sum_{t=1}^{T}\left(x_{1_{i t}}-\bar{x}_{1 i}\right)\left(y_{i t}-\bar{y}_{i}\right) \\
\sum_{i=1}^{N} \sum_{t=1}^{T}\left(x_{i_{i t}}-\bar{x}_{2_{i}}\right)\left(y_{i t}-\bar{y}_{i}\right) \\
\vdots \\
\sum_{i=1}^{N} \sum_{t=1}^{T}\left(x_{j_{i t}}-\bar{x}_{j_{i}}\right)\left(y_{i t}-\bar{y}_{i}\right)
\end{array}\right]
\end{aligned}
$$

\section{Uji Asumsi Klasik}

Model regresi data panel dapat disebut sebagai model yang baik jika model tersebut memenuhi kriteria Best Linear Unbiased Estimator (BLUE). Asumsi-asumsi untuk kriteria BLUE sebagai berikut:

\section{a. Uji Normalitas}

Uji normalitas digunakan untuk menguji apakah pada model regresi ditemukan residual yang berdistribusi normal atau tidak. Uji ini di cek menggunakan uji Jarque Berra (JB) dengan statistika uji sebagai berikut [3]:

$$
J B=N\left[\frac{S^{2}}{6}+\frac{(K-3)^{2}}{24}\right]
$$

dimana $N$ menunjukkan banyaknya data, $S$ menunjukkan skewness (kemencengan) dan $K$ menunjukkan kurtosis (keruncingan). Residual akan berdistribusi normal apabila nilai $J B<\chi_{(\alpha, 2)}^{2}$ atau $p$-value $>\alpha$.

\section{b. Uji Multikolinearitas}

Uji multikolinearitas digunakan untuk menguji apakah pada model regresi ditemukan interkorelasi atau hubungan kuat antar dua atau lebih variabel bebas. Uji ini di cek menggunakan nilai Variance Inflation Factor (VIF) dengan statistika uji sebagai berikut [3]:

$$
V I F=\frac{1}{1-R_{k}{ }^{2}}
$$

dimana $R_{k}$ menunjukkan nilai koefisien determinasi dari variabel bebas $x_{k}$ yang diregresikan terhadap variabel bebas lainnya. Apabila nilai VIF $<10$ maka tidak terdapat masalah multikolinearitas.

\section{c. Uji Autokorelasi}

Uji autokorelasi digunakan untuk menguji apakah pada model regresi ditemukan variabel bebas residual yang berkorelasi berdasarkan urutan waktu. Uji ini di cek menggunakan uji Durbin-Watson dengan statistika uji sebagai berikut [3]:

$$
d_{\text {hitung }}=\frac{\sum_{i=1}^{N} \sum_{t=1}^{T}\left(e_{i t}-e_{i . t-1}\right)^{2}}{\sum_{i=1}^{N} \sum_{t=1}^{T}\left(e_{i t}\right)^{2}}
$$

Apabila nilai $0<d_{\text {hitung }}<d_{L}$ dan $4-d_{L}<d_{\text {hitung }}<4$ maka terjadi gejala autokorelasi.

\section{d. Uji Heteroskedastisitas}

Uji heteroskedastisitas digunakan untuk menguji apakah pada model regresi ditemukan ketidaksamaan varian dari residual untuk semua pengamatan. Uji ini di cek menggunakan uji Glejser yang dinotasikan seperti [3]: 


$$
\left|e_{i}\right|=\beta_{0}+\beta_{1} x_{1}+\cdots+\beta_{j} x_{j}+u_{i}
$$

dimana $\left|e_{i}\right|$ menunjukkan nilai absolut residual yang dihasilkan dari regresi model, sedangkan $u_{i}$ menunjukkan nilai error. Penghitungan uji Glejser ini menggunakan statistika uji sebagai berikut:

$$
F_{\text {hitung }}=\frac{\left(R^{2}\right) /{ }_{N+k-1}}{\left(1-R^{2}\right) / N T-N-k}
$$

Apabila nilai $F_{\text {hitung }}>F_{\text {tabel }}=F_{\alpha ;(N-1, N T-N-k)}$ dengan $\alpha=0.05$, maka terjadi gejala heteroskedastisitas.

\section{Seemingly Uncorrelated Regression (SUR)}

Metode estimasi ini digunakan untuk mengatasi masalah autokorelasi dan heteroskedastisitas. Sebuah sistem SUR terdiri dari beberapa persamaan yang error-nya saling berkorelasi. Dimisalkan bahwa terdapat sebuah data set yang terdiri dari $N$ unit cross-section dengan observasi sejumlah $T$ periode waktu untuk setiap unit. Model SUR adalah sebuah sistem dari persamaan regresi linier yang dapat dituliskan menjadi [3]:

dapat dianalogikan menjadi:

$$
\left[\begin{array}{c}
\mathbf{y}_{1} \\
\mathbf{y}_{2} \\
\vdots \\
\mathbf{y}_{\mathrm{N}}
\end{array}\right]=\left[\begin{array}{cccc}
\mathbf{X}_{1} & 0 & \cdots & 0 \\
0 & \mathbf{X}_{2} & \cdots & 0 \\
\vdots & \vdots & \ddots & \vdots \\
0 & 0 & \cdots & \mathbf{X}_{\mathrm{N}}
\end{array}\right]\left[\begin{array}{c}
\beta_{1} \\
\beta_{2} \\
\vdots \\
\beta_{\mathrm{N}}
\end{array}\right]+\left[\begin{array}{c}
\mathbf{e}_{1} \\
\mathbf{e}_{2} \\
\vdots \\
\mathbf{e}_{\mathrm{N}}
\end{array}\right]
$$

$$
\mathbf{y}=\mathbf{X} \boldsymbol{\beta}+\mathbf{e}
$$

Matriks varian covarian dari e diberikan sebagai berikut [3]:

$$
\Omega=\left[\begin{array}{cccc}
\sigma_{11} \mathbf{I}_{\mathrm{T}} & \sigma_{12} \mathbf{I}_{\mathrm{T}} & \cdots & \sigma_{1 \mathrm{~N}} \mathbf{I}_{\mathrm{T}} \\
\sigma_{21} \mathbf{I}_{\mathrm{T}} & \sigma_{22} \mathbf{I}_{\mathrm{T}} & \cdots & \sigma_{2 \mathrm{~N}} \mathbf{I}_{\mathrm{T}} \\
\vdots & \vdots & \ddots & \vdots \\
\sigma_{\mathrm{N} 1} \mathbf{I}_{\mathrm{T}} & \sigma_{\mathrm{N} 2} \mathbf{I}_{\mathrm{T}} & \cdots & \sigma_{\mathrm{NN}} \mathbf{I}_{\mathrm{T}}
\end{array}\right]
$$

Berikut adalah estimasi parameter $\boldsymbol{\beta}$ dengan menggunakan Metode Feasible Generalized Least Square:

\section{Uji Kelayakan Model}

$$
\widehat{\beta}=\left[X^{T} \Omega^{-1} X\right]^{-1} X^{T} \Omega^{-1} \mathbf{y}
$$

Uji kelayakan model digunakan untuk mengukur ketepatan model regresi dalam menaksir nilai aktual. Macam-macam pengukuran yang dilakukan sebagai berikut:

\section{a. Uji F (Simultan)}

Uji F digunakan untuk menguji signifikansi pengaruh faktor fundamental dan faktor teknikal terhadap harga saham secara simultan atau keseluruhan dengan statistika uji sebagai berikut [3]:

$$
F_{\text {hitung }}=\frac{\left(R_{F E M^{2}}\right) /_{N+k-1}}{\left(1-R_{F E M}{ }^{2}\right) / N T-N-k}
$$

dimana $R_{F E M}{ }^{2}$ menunjukkan koefisien determinasi dari fixed effect model. Minimal terdapat satu variabel bebas yang berpengaruh secara simultan terhadap variabel tak bebas apabila nilai $F_{\text {hitung }} \geq$ $F_{\alpha ;(N-1, N T-N-k)}$.

\section{b. Uji $\boldsymbol{t}$ (Parsial)}

Uji $t$ digunakan untuk menguji signifikansi pengaruh faktor fundamental dan faktor teknikal terhadap harga saham secara parsial atau individual dengan statistika uji sebagai berikut [3]:

$$
t_{\text {hitung }}=\frac{\beta_{k}}{\sqrt{\sigma_{e}^{2} \cdot C_{k k}}}
$$


dimana $\beta_{k}$ menunjukkan nilai koefisien regresi variabel bebas $k, \sigma_{e}{ }^{2}$ menunjukkan rata-rata kuadrat residual, sedangkan $C_{k k}$ menunjukkan elemen baris ke $k$ kolom ke $k$ pada matriks penaksir parameter $\boldsymbol{\beta}$. Variabel bebas yang diuji berpengaruh secara parsial terhadap variabel tak bebas apabila $\left|t_{\text {hitung }}\right| \geq$ $t_{(\alpha ; N T-k)}$.

\section{c. Koefisien Determinasi}

Koefisien determinasi $\left(R^{2}\right)$ digunakan untuk mengukur seberapa kuat hubungan semua variabel bebas terhadap variabel tak bebasnya dengan statistika uji sebagai berikut [3]:

$$
R^{2}=\frac{\mathrm{JKR}}{\mathrm{JKT}}
$$

dimana JKR menunjukkan jumlah kuadrat regresi, sedangkan JKT menunjukkan jumlah kuadrat total. Apabila nilai $R^{2}$ mendekati 1 , maka dapat dikatakan pengaruh semua variabel bebas terhadap variabel tak bebasnya sangat signifikan.

\section{Hasil dan Diskusi}

\section{Data Penelitian}

Data yang digunakan pada penelitian ini adalah laporan keuangan triwulan perusahaan Agung Podomoro Land Tbk, Alam Sutera Realty Tbk, Duta Anggada Realty Tbk, Fortune Mate Indonesia Tbk, Greenwood Sejahtera Tbk, Jaya Real Property Tbk, Modernland Realty Tbk, Metropolitan Land Tbk, Metro Realty Tbk, dan Pakuwon Jati Tbk periode 2016 sampai 2018. Data tersebut diperoleh dari Bursa Efek Indonesia [4].

Variabel tak bebas yang digunakan:

$y$ : harga saham

Variabel bebas faktor fundamental yang digunakan:

$x_{1}$ : return on asset

$x_{2}$ : price to book value

$x_{3}$ : earning per share

$x_{4}$ : debt to equtity ratio

variabel bebas faktor teknikal yang digunakan:

$x_{5}$ : volume perdagangan saham

\section{Estimasi Parameter FEM dengan Metode LSDV}

Estimasi parameter model regresi data panel pada harga saham menggunakan pendekatan fixed effect model dengan metode least square dummy variable. Berdasarkan persamaan (5) dan (6) dengan bantuan software Maple 17 dan MS.Excel 2016 diperoleh model taksiran sebagai berikut:

$$
\begin{aligned}
\widehat{y_{l t}}= & 4,081723 D_{1 t}+4,230311 D_{2 t}+4,117668 D_{3 t}+1,216626 D_{4 t}+0,950675 D_{5 t}+2,958112 D_{6 t} \\
& +1,317686 D_{7 t}+2,321739 D_{8 t}+3,785426 D_{9 t}+2,418954 D_{10 t}-0,036582 x_{1 i t} \\
& +2,086180 x_{2_{i t}}+1,083967 x_{3 i t}-1,834684 x_{4 i t}-0,180297 x_{5 i t}
\end{aligned}
$$

Berdasarkan model di atas, dapat dijelaskan bahwa setiap kenaikan return on asset sebesar $1 \%$, maka harga saham akan turun sebesar $0,036582 \%$. Setiap kenaikan price to book value sebesar $1 \%$, maka harga saham akan naik sebesar 2,086180\%. Setiap kenaikan earning per share sebesar $1 \%$, maka harga saham akan naik sebesar $1,083967 \%$. Setiap kenaikan debt to equity ratio sebesar $1 \%$, maka harga saham akan turun sebesar 1,834684\% dan untuk setiap kenaikan volume perdagangan saham sebesar $1 \%$ maka harga saham akan naik sebesar $0,180297 \%$. Kemudian $D_{1}, D_{2}, \ldots, D_{10}$ merupakan variabel dummy untuk 
mengetahui perbedaan intersep antara perusahaan tempat berinvestasi saham yang menjelaskan efek perbedaan perusahaan.

\section{Pengujian Asumsi Klasik}

a. Hasil Uji Normalitas

Uji normalitas digunakan untuk menguji apakah pada model regresi ditemukan residual yang berdistribusi normal atau tidak. Uji ini di cek menggunakan uji Jarque Berra (JB).

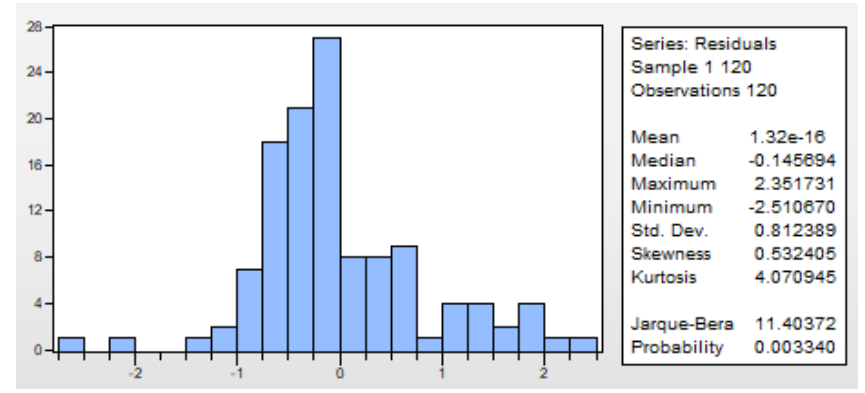

Gambar 1. Histogram residual dengan data asli

Berdasarkan Gambar 1 diperoleh nilai probabilitas sebesar 0,003340. Dengan nilai signifikasi $(\alpha)$ 0,05 terlihat bahwa nilai probabilitas $<\alpha$. Sehingga dapat disimpulkan bahwa residual dari model FEM tidak berdistribusi normal. Untuk mengatasi data yang residualnya tidak bedistribusi normal, maka perlu dilakukan transformasi data dengan logaritma natural.

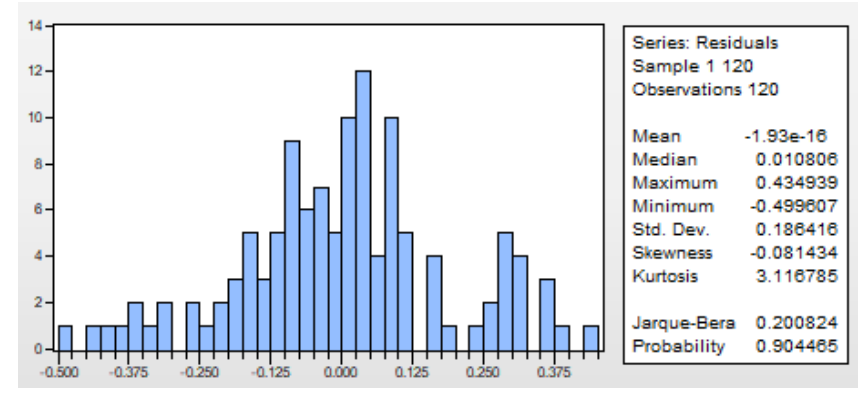

Gambar 2. Histogram residual dengan data logaritma natural

Setelah dilakukan transformasi data dengan logaritma natural (In), berdasarkan Gambar 2 diperoleh nilai probabilitas baru sebesar 0,904465 . Dengan nilai signifikasi $(\alpha) 0,05$ terlihat bahwa nilai probabilitas $>\alpha$. Sehingga dapat disimpulkan bahwa residual dari model FEM dengan data transformasi sudah berdistribusi normal.

\section{b. Hasil Uji Multikolinearitas}

Uji multikolinearitas digunakan untuk menguji apakah pada model regresi ditemukan interkorelasi atau hubungan kuat antar dua atau lebih variabel bebas. Uji ini di cek menggunakan nilai Variance Inflation Factor (VIF), berdasarkan persamaan (8) diperoleh nilai VIF tiap-tiap variabel sebagai berikut:

$V I F_{1}=\frac{1}{1-R_{1}^{2}}=\frac{1}{1-0,802286783^{2}}=2,80634$

$V I F_{2}=\frac{1}{1-R_{2}{ }^{2}}=\frac{1}{1-0,403154675^{2}}=1,19408$ 
$V I F_{3}=\frac{1}{1-R_{3}^{2}}=\frac{1}{1-0,773161498^{2}}=2,48619$

$V I F_{4}=\frac{1}{1-R_{4}^{2}}=\frac{1}{1-0,480729192^{2}}=1,30056$

$V I F_{5}=\frac{1}{1-R_{5}^{2}}=\frac{1}{1-0,412986458^{2}}=1,20563$

Karena nilai VIF < 10 maka tidak terdapat masalah multikolinearitas pada model FEM.

\section{c. Hasil Uji Autokorelasi}

Uji autokorelasi digunakan untuk menguji apakah pada model regresi ditemukan variabel bebas residual yang berkorelasi berdasarkan urutan waktu. Uji ini di cek menggunakan uji Durbin-Watson, berdasarkan persamaan (9) dan bantuan software Eviews 9 diperoleh nilai $d_{\text {hitung }}$ sebesar 0,0524373. Terlihat bahwa nilai $d_{\text {hitung }}<d_{L}=1,6164$, sehingga dapat disimpulkan bahwa terjadi gejala autokorelasi antar residual pada model FEM.

\section{d. Hasil Uji Heteroskedastisitas}

Uji heteroskedastisitas digunakan untuk menguji apakah pada model regresi ditemukan ketidaksamaan varian dari residual untuk semua pengamatan. Uji ini di cek menggunakan uji Glejser, berdasarkan persamaan (10), persamaan (11) dan bantuan software Eviews 9 diperoleh nilai $F_{\text {hitung }}$ sebesar 9,24765. Terlihat bahwa nilai $F_{\text {hitung }}>F_{\text {tabel }}=F_{0.05 ;(9,105)}=1,97$, sehingga dapat disimpulkan bahwa terjadi gejala heteroskedastisitas pada model FEM.

\section{Estimasi Parameter FEM dengan Metode SUR}

Karena pada model FEM terjadi gejala autokorelasi dan heteroskedastisitas, maka gejala tersebut dapat teratasi dengan metode Seemingly Uncorrelated Regression. Berdasarkan persamaan (12) dengan bantuan software Eviews 9 diperoleh model taksiran sebagai berikut:

$$
\begin{aligned}
\widehat{y_{l t}}= & 1,609513 D_{1 t}+1,473034 D_{2 t}+2,098985 D_{3 t}+0,895837 D_{4 t}+1,301665 D_{5 t}+1,458542 D_{6 t} \\
& +1,621554 D_{7 t}+1,186654 D_{8 t}+0,787439 D_{9 t}+1,147947 D_{10 t}-0,021321 x_{1 i t} \\
& +0,774095 x_{2_{i t}}+0,045573 x_{3 i t}-0,166860 x_{4 i t}-0,011933 x_{5 i t}
\end{aligned}
$$

Berdasarkan model di atas, dapat dijelaskan bahwa setiap kenaikan return on asset sebesar $1 \%$, maka harga saham akan turun sebesar $0,021321 \%$. Setiap kenaikan price to book value sebesar $1 \%$, maka harga saham akan naik sebesar 0,774095\%. Setiap kenaikan earning per share sebesar $1 \%$, maka harga saham akan naik sebesar $0,045573 \%$. Setiap kenaikan debt to equity ratio sebesar $1 \%$, maka harga saham akan turun sebesar $0,166860 \%$ dan untuk setiap kenaikan volume perdagangan saham sebesar $1 \%$ maka harga saham akan turun sebesar $0,011933 \%$. Kemudian $D_{1}, D_{2}, \ldots, D_{10}$ merupakan variabel dummy untuk mengetahui perbedaan intersep antara perusahaan tempat berinvestasi saham yang menjelaskan efek perbedaan perusahaan.

\section{Pengujian Kelayakan Model}

\section{a. Hasil Uji F (Simultan)}

Uji F digunakan untuk menguji signifikansi pengaruh faktor fundamental dan faktor teknikal terhadap harga saham secara simultan atau keseluruhan. Berdasarkan persamaan (13) dan bantuan software Eviews 9 diperoleh nilai $F_{\text {hitung }}$ sebesar 113141,7. Terlihat bahwa nilai $F_{\text {hitung }}>F_{\text {tabel }}=$ $F_{0.05 ;(9,105)}=1,97$, sehingga dapat disimpulkan bahwa minimal terdapat satu variabel bebas yang berpengaruh secara simultan terhadap variabel tak bebas. 


\section{b. Hasil Uji $\boldsymbol{t}$ (Parsial)}

Uji $t$ digunakan untuk menguji signifikansi pengaruh faktor fundamental dan faktor teknikal terhadap harga saham secara parsial atau individual. Berdasarkan persamaan (14) dan bantuan software Eviews 9 diperoleh nilai $t_{\text {hitung }}$ pada Tabel 1:

Tabel 1. Hasil Uji $t$ dengan Eviews 9

\begin{tabular}{lr}
\hline \multicolumn{1}{c}{ Variabel } & $t_{\text {hitung }}$ \\
\hline$x_{1}$ (return on asset) & $-3,424157$ \\
$x_{2}$ (price to book value) & 99,90697 \\
$x_{3}$ (earning per share) & 7,402563 \\
$x_{4}$ (debt to equity ratio) & $-25,54939$ \\
$x_{5}$ (volume perdagangan saham) & $-18,96756$ \\
\hline
\end{tabular}

Berdasarkan Tabel 1 diperoleh nilai $\left|t_{\text {tabel }}\right|=t_{(0.05 ; 115)}=1,65821$. Sehingga faktor yang berpengaruh signifikan terhadap harga saham secara parsial adalah $\mathrm{x}_{1}$ (return on asset), $\mathrm{x}_{2}$ (price to book value), $\mathrm{x}_{3}$ (earning per share), $\mathrm{x}_{4}$ (debt to equity ratio), dan $\mathrm{x}_{5}$ (volume perdagangan saham).

\section{c. Nilai Koefisien Determinasi}

Koefisien determinasi digunakan untuk mengukur seberapa kuat hubungan semua variabel bebas terhadap variabel tak bebasnya. Berdasarkan persamaan (15) dan bantuan software Eviews 9 diperoleh nilai $R^{2}$ sebesar 0,999934. Sehingga pengaruh return on asset, price to book value, earning per share, debt to equity ratio, dan volume perdagangan saham terhadap harga saham sebesar $99,9934 \%$. sedangkan 0,0066\% sisanya dipengaruhi oleh faktor-faktor lain yang tidak dimasukkan kedalam model.

\section{Interpretasi Fixed Effect Model}

Data yang digunakan pada model masih merupakan transformasi logaritma natural, sehingga data harus diubah memakai anti In. Sehingga taksiran model regresi data panel fixed effect untuk 10 saham sektor industri real estate di Bursa Efek Indonesia adalah sebagai berikut:

1. Agung Podomoro Land Tbk

$$
\hat{y}_{1 t}=5,000375+0,978905 x_{1_{1 t}}+2,168629 x_{2_{1 t}}+1,046627 x_{3_{1 t}}+0,846318 x_{4_{1 t}}+0,988138 x_{5_{1 t}}
$$

2. Alam Sutera Realty Tbk

$$
\hat{y}_{2 t}=4,362451+0,978905 x_{12 t}+2,168629 x_{22 t}+1,046627 x_{32 t}+0,846318 x_{42 t}+0,988138 x_{5_{2 t}}
$$

3. Duta Aggada Realty Tbk

$$
\hat{y}_{3 t}=8,157885+0,978905 x_{1_{3 t}}+2,168629 x_{2_{3 t}}+1,046627 x_{33 t}+0,846318 x_{43 t}+0,988138 x_{5_{3 t}}
$$

4. Fortune Mate Indonesia Tbk

$$
\hat{y}_{4 t}=2,449385+0,978905 x_{14 t}+2,168629 x_{2_{4 t}}+1,046627 x_{34 t}+0,846318 x_{44 t}+0,988138 x_{5_{4 t}}
$$

5. Greenwood Sejahtera Tbk

$$
\hat{y}_{5 t}=3,675411+0,978905 x_{1_{5 t}}+2,168629 x_{2_{5 t}}+1,046627 x_{35 t}+0,846318 x_{4_{5 t}}+0,988138 x_{55 t}
$$

6. Jaya Real Property Tbk

$$
\hat{y}_{6 t}=4,299686+0,978905 x_{16 t}+2,168629 x_{26 t}+1,046627 x_{36 t}+0,846318 x_{46 t}+0,988138 x_{56 t}
$$

7. Modernland Realty Tbk

$$
\hat{y}_{7 t}=5,060949+0,978905 x_{17 t}+2,168629 x_{27 t}+1,046627 x_{37 t}+0,846318 x_{47 t}+0,988138 x_{57 t}
$$

8. Metropolitan Land Tbk

$$
\hat{y}_{8 t}=3,276101+0,978905 x_{1_{8 t}}+2,168629 x_{2_{8 t}}+1,046627 x_{3_{8 t}}+0,846318 x_{4_{8 t}}+0,988138 x_{5_{8 t}}
$$

9. Metro Realty Tbk 


$$
\hat{y}_{9 t}=2,197761+0,978905 x_{19 t}+2,168629 x_{29 t}+1,046627 x_{39 t}+0,846318 x_{49 t}+0,988138 x_{59 t}
$$

10. Pakuwon Jati Tbk

$$
\hat{y}_{10 t}=3,151716+0,978905 x_{10 t}+2,168629 x_{210 t}+1,046627 x_{3_{10 t}}+0,846318 x_{4_{10 t}}+0,988138 x_{5_{10 t}}
$$

Berdasarkan model di atas, dapat dijelaskan bahwa setiap kenaikan return on asset sebesar $1 \%$, maka harga saham akan naik sebesar $0,978905 \%$. Setiap kenaikan price to book value sebesar $1 \%$, maka harga saham akan naik sebesar 2,168629\%. Setiap kenaikan earning per share sebesar $1 \%$, maka harga saham akan naik sebesar $1,046627 \%$. Setiap kenaikan debt to equity ratio sebesar $1 \%$, maka harga saham akan naik sebesar $0,846318 \%$ dan untuk setiap kenaikan volume perdagangan saham sebesar $1 \%$ maka harga saham akan naik sebesar 0,988138\%.

Efek perbedaan perusahaan tempat berinvestasi saham dijelaskan melalui nilai intersep yang berbeda-beda. Nilai intersep masing-masing perusahaan adalah Agung Podomoro Land Tbk sebesar 5,000375, Alam Sutera Realty Tbk sebesar 4,362451, Duta Anggada Realty Tbk sebesar 8,157885, Fortune Mate Indonesia Tbk sebesar 2,449385, Greenwood Sejahtera Tbk sebesar 3,675411, Jaya Real Property Tbk sebesar 4,299686, Modernland Realty Tbk sebesar 5,060949, Metropolitan Land Tbk sebesar 3,276101, Metro Realty Tbk sebesar 2,197761, dan Pakuwon Jati Tbk sebesar 3,151716.

\section{Kesimpulan}

Berdasarkan hasil dan pembahasan pada pada bab sebelumnya, dapat disimpulkan bahwa bahwa faktor fundamental (return on asset, price to book value, earning per share, dan debt to equity ratio) dan faktor teknikal (volume perdagangan saham) berpengaruh secara simultan maupun parsial terhadap harga saham sektor industri real estate di Bursa Efek Indonesia.

\section{Ucapan Terima Kasih}

Penulis mengucapkan terima kasih kepada Bursa Efek Indonesia terkait data penelitian, serta seluruh pihak yang tidak dapat disebutkan satu persatu.

\section{Referensi}

[1] Adha, C., dan Dewi, F. R. 2014. Pengaruh Kinerja Keuangan terhadap Harga Saham PerusahaanPerusahaan Produsen Kabel yang Terdaftar di Bursa Efek Indonesia. Jurnal Manajemen dan Organisasi. Vol. 5, No. 1.

[2] Samsuar, T. dan Akramunnas. 2017. Pengaruh Faktor Fundamental dan Teknikal Terhadap Harga Saham Industri Perhotelan Yang Terdaftar Di Bursa Efek Indonesia. Jurnal Ekonomi, Keuangan dan Perbankan Syariah. Vol. 1, No. 1.

[3] Srihardianti, M., Mustafid \& Prahutama, A., 2016. Metode regresi data panel untuk peramalan konsumsi energi di Indonesia. Jurnal Gaussian. Vol. 5, No. 3, 2339-2541.

[4] https://www.idx.co.id// [diakses 20 September 2019]. 